Review Article

\title{
Progress of Metal Oxide (Sulfide)-Based Photocatalytic Materials for Reducing Nitrogen to Ammonia
}

\author{
Jianjun Yang $\mathbb{D}^{1,2}$ \\ ${ }^{1}$ Department of Chemical Engineering, School of Environment Science and Engineering, Chang'an University, \\ Xi'an 710054, China \\ ${ }^{2}$ Key Laboratory of Subsurface Hydrology and Ecological Effects in Arid Region, Chang'an University, \\ Ministry of Education, Xi'an 710054, China \\ Correspondence should be addressed to Jianjun Yang; mysyjj@163.com
}

Received 13 July 2018; Revised 1 November 2018; Accepted 5 November 2018; Published 22 November 2018

Academic Editor: Mallikarjuna N. Nadagouda

Copyright ( 2018 Jianjun Yang. This is an open access article distributed under the Creative Commons Attribution License, which permits unrestricted use, distribution, and reproduction in any medium, provided the original work is properly cited.

\begin{abstract}
The Haber-Bosch process has been an important approach to produce ammonia for meeting the food need of increasing population and the worldwide need of nitrogenous fertilizers since 1913. However, the traditional ammonia production process is a high energy-consumption process, which usually produces 1 metric ton ammonia with releasing around 1.9 metric tons $\mathrm{CO}_{2}$. Photocatalytic ammonia synthesis under solar light as energy source, an attractive and promising alternative approach, is a very challenging target of reducing fossil energy consumption and environmental pollution. Therefore, photocatalytic ammonia production process would emerge huge opportunities by directly providing nitrogenous fertilizers in a distributed manner as needed in the agricultural fields. In this article, different metal oxide (sulfide)-based photocatalytic materials for reducing nitrogen to ammonia under ambient conditions are reviewed. This review provides insights into the most recent advancements in understanding the photocatalyst materials which are of fundamental significance to photocatalytic nitrogen reduction, including the state-of-the-art, challenges, and prospects in this research field.
\end{abstract}

\section{Introduction}

As the important chemicals to our planet, nitrogen $\left(\mathrm{N}_{2}\right)$ compounds, such as ammonia $\left(\mathrm{NH}_{3}\right)$, nitrates, and urea, have played an essential role in meeting the growing demand for food and the worldwide need of nitrogenous fertilizer since 1913 [1]. It is essential for all living organisms to being provided the $\mathrm{N}_{2}$ compounds needed for growing tissue [2]. Moreover, the global $\mathrm{N}_{2}$ cycle, whose small fraction is related to the atmospheric ionization, mainly depends on the biogeochemical cycles [3]. In addition, $\mathrm{N}_{2}$ photoreduction to nitrogenous compounds (e.g., $\mathrm{NH}_{3}$ ) in soils and sands as catalysts also is an important part of global $\mathrm{N}_{2}$ cycle. Through continuous exploration of nitrogen fixation, the Haber-Bosch process, a thermo-chemical catalytic conversion technology, becomes a primary choice of synthesizing $\mathrm{N}_{2}$ fixation compounds which were produced from the reaction:

$$
\mathrm{N}_{2}+3 \mathrm{H}_{2} \longrightarrow 2 \mathrm{NH}_{3}
$$

In the past over decades [4], the process has fed the world's growing population and has significantly contributed to the human beings development. The Haber-Bosch process reacted with the pure feed gases at high temperatures and pressures, requiring almost $2 \%$ of global energy consumption [5]. On the contrary, there are some negative impacts of the Haber-Bosch process in terms of the overuse of nitrogenous fertilizer that affects the ecosystem balance, human health, climate change, etc. [6]. Then, reducing the fossil energy consumption and environmental pollution would be a very challenging target for this process.

Ambient reduction of $\mathrm{N}_{2}$ to $\mathrm{NH}_{3}$ has been a significant research subject of efficiently fixing $\mathrm{N}_{2}$ under mild conditions. Energy coming from sustainable source as solar, an alternative, sustainable $\mathrm{NH}_{3}$ synthesis process based on the biological $\mathrm{N}_{2}$ fixation would be more energy efficient than 
the Haber-Bosch process [7]. Additionally, the distribution of nitrogenous fertilizers produced by the Haber-Bosch process requires efficient transportation which may be least easy in the nonindustrialized countries than in the industrialized countries. Then, it would be possible to produce nitrogenous fertilizers close to the farm field as needed and reduce greenhouse gas emission and control the global $\mathrm{N}_{2}$ cycle. Obviously, due to its energy saving and friendly environmental, photocatalytic reduction of $\mathrm{N}_{2}$ to $\mathrm{NH}_{3}$ could be an excellent alternative to the Haber-Bosch process. That is to say, developing efficient photocatalysts for synthesizing $\mathrm{NH}_{3}$ would emerge huge opportunity to directly provide nitrogenous fertilizers in agricultural fields as needed in a distributed manner. Chemists should discover how to activate the $\mathrm{N} \equiv \mathrm{N}$ bond $\left(941 \mathrm{~kJ} \cdot \mathrm{mol}^{-1}\right)$ to synthesize ammonia in the presence of novel photocatalysts with less fossil energy consumption and more solar energy [8].

In initial works, there was a popular perspective that the photocatalytic reduction of $\mathrm{N}_{2}$ to $\mathrm{NH}_{3}$ should take place over abundant soil minerals and sand in nature [9]. Since 1977, the $\mathrm{TiO}_{2}$-based synthetic materials as photocatalysts were firstly applied for $\mathrm{N}_{2}$ fixation under UV light, and a series of studies [10] have gradually been conducted on photocatalytic $\mathrm{N}_{2}$ reduction to $\mathrm{NH}_{3}$ with water and air under light driving force. Although there have been many new photocatalysts and approaches to solve the problems of the Haber-Bosch process, till now, no viable and efficient catalysts could match all requirements of an active, selective, scalable, long-lived catalyst for the sustainable photocatalytic reduction of $\mathrm{N}_{2}$ to $\mathrm{NH}_{3}$ [11]. This review tries to make them possible to ascertain a comprehensive understanding of the current knowledge regarding to photocatalytic materials for producing nitrogenous fertilizers from $\mathrm{N}_{2}$ and to give a solid research perspectives for the next step work in the research field.

\section{Photocatalytic Reduction Process of $\mathbf{N}_{2}$ to $\mathbf{N H}_{3}$}

The photocatalytic reduction of $\mathrm{N}_{2}$ to $\mathrm{NH}_{3}$ under ambient conditions is a sustainable $\mathrm{NH}_{3}$ production process without fossil energy consumption and environmental pollutions. Photocatalysis on semiconductors is a promising method for synthesizing $\mathrm{NH}_{3}$ from $\mathrm{N}_{2}$ with water $\left(\mathrm{H}_{2} \mathrm{O}\right)$ as a reducing reagent. The photocatalytic $\mathrm{NH}_{3}$ production process mainly consists of the photocatalytic oxidation of $\mathrm{H}_{2} \mathrm{O}$ to protons and the photocatalytic reduction of $\mathrm{N}_{2}$ to $\mathrm{NH}_{3}$.

$$
\begin{gathered}
\mathrm{H}_{2} \mathrm{O}+2 \mathrm{~h}^{+} \longrightarrow 0.5 \mathrm{O}_{2}+2 \mathrm{H}^{+} \\
\mathrm{N}_{2}+6 \mathrm{H}^{+}+6 \mathrm{e}^{-} \longrightarrow 2 \mathrm{NH}_{3} \\
2 \mathrm{~N}_{2}+3 \mathrm{H}_{2} \mathrm{O} \underset{\text { photocatalyst }}{\stackrel{\text { light }}{\longrightarrow}} 2 \mathrm{NH}_{3}+1.5 \mathrm{O}_{2}
\end{gathered}
$$

The reactions mentioned above imply that the photocatalysts created on the surface of robust semiconductors capable of oxidizing $\mathrm{H}_{2} \mathrm{O}$ (Equation (2)) may reduce $\mathrm{N}_{2}$ by the photoformed conduction band (CB) electrons (Equation (3)). As a result of these behaviours, $\mathrm{N}_{2}$ is reduced to $\mathrm{NH}_{3}$ by the $\mathrm{CB}$ electrons (Equation (2)). That is to say, $\mathrm{NH}_{3}$ could be produced from $\mathrm{N}_{2}$ and $\mathrm{H}_{2} \mathrm{O}$ (Equation (4)) on a metal-free photocatalyst under ambient conditions in these processes. The valence band (VB) should be lower than the oxygen evolution potential, while the position of the $\mathrm{CB}$ should be higher than the reduction potential of $\mathrm{N}_{2}$ hydrogenation. With synthesizing ammonia, the metal oxide-based material as photocatalyst is dynamically converted between its oxidized and reduced states in the process.

Solar light as energy source is a good choice for photocatalytic reduction of $\mathrm{N}_{2}$ to $\mathrm{NH}_{3}$ under ambient conditions because it is difficult for the existing power plants to meet the large energy need of producing $\mathrm{NH}_{3}$ (Figure 1). The $\mathrm{CB}$ position of the semiconductor should be more negative than the reduction potential of the $\mathrm{N}_{2}$ hydrogenation, as well as the VB should be more positive than the oxygen evolution potential (Table 1). Therefore, something must be taken into account that both reduction potential of the adsorbate and position of the energy band are important for the photocatalytic redox reaction occurrence when making a decision on the choice of semiconductor photocatalyst materials.

Normally, the photocatalytic reduction process of $\mathrm{N}_{2}$ to $\mathrm{NH}_{3}$ can be divided into several reaction steps $[13,14]$. Firstly, the photogenerated electrons $\left(\mathrm{e}^{-}\right)$are promoted to leave from vacant holes in the VB to the CB. Secondly, some electrons and holes recombine each other in order to improve the solar conversion efficiency and apparent quantum yield of the reduction. Protons could be generated in the endothermic process of $\mathrm{H}_{2} \mathrm{O}$ oxidation when solar energy is enough to be absorbed and converted into the chemical energy which can meet the large free energy gain of $\mathrm{N}_{2}$ to $\mathrm{NH}_{3}\left(\Delta G^{0}=339 \mathrm{~kJ} \cdot \mathrm{mol}^{-1}\right)$ [15]. Thirdly, the others transfer onto the surface of the photocatalysts for the redox reaction (Equation (4)) which the photoformed VB holes $\left(\mathrm{h}^{+}\right)$oxidize $\mathrm{H}_{2} \mathrm{O}$ to protons $\left(\mathrm{H}^{+}\right)$and $\mathrm{O}_{2}$ under visible light. In the process of photocatalytic ammonia synthesis, the photogenerated holes must also be consumed to satisfy the charge neutrality $\left(\mathrm{CB} \mathrm{e}^{-}+\mathrm{VB} \mathrm{h}^{+}=0\right)$ (Equation (2) in Table 1).

By synthesizing $\mathrm{NH}_{3}$ from atmospheric $\mathrm{N}_{2}$ and $\mathrm{H}_{2} \mathrm{O}$ in the presence of photocatalysts under visible light (Equation (3)) [16], photons as the driving force actually can promote to reduce $\mathrm{N}_{2}$ to $\mathrm{NH}_{3}$ after a series of multistep injections of photogenerated electrons and $\mathrm{H}_{2} \mathrm{O}$-derived protons. Therefore, the first electron transfer $(-4.16 \mathrm{~V}$ vs. NHE) and proton-coupled electron transfer $(-3.2 \mathrm{~V}$ vs. NHE) (Table 1$)$ must be overcome to reduce $\mathrm{N}_{2}$ to $\mathrm{NH}_{3}$. Then, the recombination of charge carriers and a small band gap are important for satisfying semiconductor photocatalysts preferably in the visible light. And it is also necessary for ideal semiconductor materials to have the characteristics of the charge carrier recombination and a small band gap in the visible light region.

\section{Photocatalytic Materials for Reducing $\mathbf{N}_{2}$ to $\mathrm{NH}_{3}$}

As we all know, photocatalytic $\mathrm{NH}_{3}$ synthesis from $\mathrm{N}_{2}$ also needs to overcome the $\mathrm{N} \equiv \mathrm{N}$ band energy barrier with the high-energy UV light. Necessarily, the large thermodynamic 


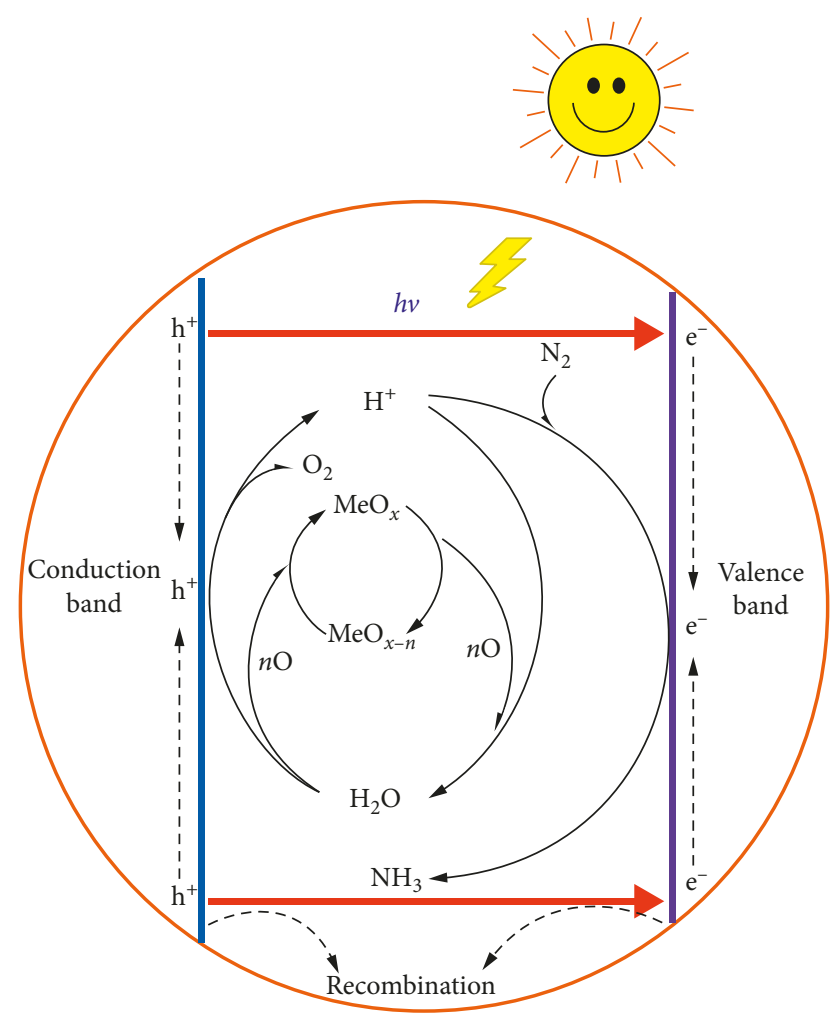

FIGURE 1: Schematic of metal oxide-based photocatalysts for reducing $\mathrm{N}_{2}$ to $\mathrm{NH}_{3}$. $\mathrm{MeO}_{x}\left(\mathrm{MeO}_{x-n}\right)$ : metal oxide-based materials as photocatalysts and Me denotes metals.

TABLE 1: Redox potentials of reducing $\mathrm{N}_{2}$ to $\mathrm{NH}_{3}$ [10-12]].

\begin{tabular}{lcc}
\hline No. & Reaction & $E^{0}(\mathrm{~V})$ \\
\hline 1 & $\mathrm{H}_{2} \mathrm{O}+2 \mathrm{~h}^{+} \longrightarrow 0.5 \mathrm{O}_{2}+2 \mathrm{H}^{+}$ & $1.33^{\mathrm{b}}$ \\
2 & $\mathrm{H}^{+}+\mathrm{e}^{-} \longrightarrow 0.5 \mathrm{H}_{2}$ & $-0.42^{\mathrm{a}}$ \\
3 & $\mathrm{~N}_{2}+\mathrm{e}^{-} \longrightarrow \mathrm{N}_{2}^{-}$ & $-4.16^{\mathrm{b}}$ \\
4 & $\mathrm{~N}_{2}+\mathrm{H}^{+}+\mathrm{e}^{-} \longrightarrow \mathrm{N}_{2} \mathrm{H}$ & $-3.2^{\mathrm{b}}$ \\
5 & $\mathrm{~N}_{2}+6 \mathrm{H}^{+}+6 \mathrm{e}^{-} \longrightarrow 2 \mathrm{NH}_{3}$ & $0.55^{\mathrm{b}}$ \\
\hline
\end{tabular}

${ }^{\mathrm{a}} E^{0}$ vs. NHE at $\mathrm{pH} 7 ;{ }^{\mathrm{b}} E^{0}$ vs. NHE at $\mathrm{pH} 0$.

driving force is required for the reduction of $\mathrm{N}_{2}$ to $\mathrm{NH}_{3}$ at atmospheric conditions [17]. To solve the problem, developing the efficient photocatalytic materials for the $\mathrm{N}_{2}$ reduction process maybe are indispensable parts for increasing $\mathrm{NH}_{3}$ yields significantly.

It is first time that Dhar and his coworkers [18] discovered this photocatalytic reaction in the 1940s. Schrauzer and Guth [13] demonstrated that the photocatalytic $\mathrm{NH}_{3}$ synthesis on a variety of sterile desert sands until late 1970s. Following this work, some independent results were achieved as gaining synthetic materials for speeding the photocatalytic $\mathrm{N}_{2}$ reduction rate [19]. However, there are still some differences among these results some of which are in conflict with each other or confused, and no consensus was reached in regard to the photocatalytic materials challenges for the reaction of $\mathrm{N}_{2}$ and $\mathrm{H}_{2} \mathrm{O}$ to $\mathrm{NH}_{3}$ and oxygen. In this section, the metal oxide-based photocatalytic materials for the reduction of $\mathrm{N}_{2}$ to $\mathrm{NH}_{3}$ are classified (Tables 2 and 3) according to their different elemental compositions and the state-of-the-art research advancements are described, respectively.

3.1. Titanium Oxide-Based Materials. Photocatalytic $\mathrm{N}_{2}$ fixation has received more and more attentions since synthesizing $\mathrm{NH}_{3}$ from $\mathrm{N}_{2}$ was available in the presence of titanium-based catalysts. Dhar and Chowdhry [43] found that titanium oxide $\left(\mathrm{TiO}_{2}\right)$ as photocatalytic material could provide the larger $\mathrm{NH}_{3}$ yields from reducing $\mathrm{N}_{2}$ than ferric oxide and zinc oxide as photocatalysts. Schrauzer and Guth [13] also discovered this phenomenon of $\mathrm{N}_{2}$ photoreduction. UV irradiation of $\mathrm{TiO}_{2}$ with a large number of surface $\mathrm{Ti}^{3+}$ species could produce $\mathrm{NH}_{3}$ from $\mathrm{N}_{2}$ and $\mathrm{H}_{2} \mathrm{O}$ under ambient conditions, which shows the species are actually the active sites for the reduction of $\mathrm{N}_{2}$ to $\mathrm{NH}_{3}$ [14].

3.1.1. Iron-Doped Materials. As key factors underlying photocatalytic performance, the influence of the crystalline phase and iron dopants on the catalytic activity of $\mathrm{TiO}_{2}$ photocatalytic material for the $\mathrm{N}_{2}$ reduction was focused. Under UV light, $\mathrm{NH}_{3}$ yields reached a maximum value when over $0.2 \% \mathrm{Fe}_{2} \mathrm{O}_{3}$ was doped into $\mathrm{TiO}_{2}$ material. However, Hirakawa et al. [14] demonstrated that Ru, Pt, or Pd particles loaded in the $\mathrm{TiO}_{2}$ materials were unhelpful to increase the $\mathrm{NH}_{3}$ yields due to their particles covering the catalytic active site $\mathrm{Ti}^{3+}$ of $\mathrm{TiO}_{2}$ photocatalytic material and changing surface defects. Interestingly, Augugliaro et al. [44] supported $\mathrm{Fe}_{2} \mathrm{O}_{3}$-hybridized $\mathrm{TiO}_{2}$ on $\mathrm{Al}_{2} \mathrm{O}_{3}$ as photocatalyst which was applied in gas-solid fluidized bed reactors to improve $\mathrm{NH}_{3}$ yields because of the influence of iron ions on the $\mathrm{TiO}_{2}$ crystalline [45]. Lashgari and Zeinalkhani [21] photosynthesized $\mathrm{NH}_{3}$ in a $\mathrm{H}_{2} \mathrm{O}$ photosplitting setup in the presence of some synthetic $\mathrm{Fe}_{2} \mathrm{O}_{3}$ and $\mathrm{TiO}_{2}$-based uniform nanoparticles and obtained the maximum $\mathrm{NH}_{3}$ yield. Bourgeois et al. [26] suggested that thermal pretreatments could generate surface defects or impurity states on the surface of unmodified $\mathrm{TiO}_{2}$ that showed the photocatalytic activity of reducing $\mathrm{N}_{2}$ after annealing in air. As a highly efficient method, high pretreatment temperatures $\left(\sim 1000^{\circ} \mathrm{C}\right)$ inducing surface defects in $\mathrm{TiO}_{2}$ material and the small amounts $(<1 \%)$ of iron impurities are necessary to enhance the $\mathrm{NH}_{3}$ yields [46].

Observing no reduction of $\mathrm{N}_{2}$ to $\mathrm{NH}_{3}$ in the presence of pure $\mathrm{TiO}_{2}$ material, Augugliaro et al. [47] put forward a hypothesis that $\mathrm{Fe}^{3+}$ of photoassisted organ iron compound could temporarily trap photons and promote the separation of charge carriers, which has played an important role in the $\mathrm{NH}_{3}$ production processes. Exposing the facets of $\mathrm{Fe}$-doped $\mathrm{TiO}_{2}$ with ethanol as the scavenger enhanced the photocatalytic reduction of $\mathrm{N}_{2}$ to $\mathrm{NH}_{3}$ [22]. No nitrite was formed in the ethanol solution that could prevent the oxidation of $\mathrm{NH}_{3}$. Keeping a low doping concentration on the surface of $\mathrm{TiO}_{2}$ material was very important to inhibit charge recombination for forming $\mathrm{Fe}^{2+}$ and $\mathrm{Fe}^{4+}$ and to transfer electrons and holes to $\mathrm{Ti}^{4+}$ and $\mathrm{OH}^{-}$for generating $\mathrm{Ti}^{3+}$ and $\mathrm{OH}$ [18]. Similarly, Ranjit and Viswanathan [48] observed that the $\mathrm{FeTi}_{2} \mathrm{O}_{5}$ phase in $\mathrm{Fe}$-doped titanium materials could 
TABLE 2: Summary of metal oxide-based materials for photocatalytic reduction of $\mathrm{N}_{2}$ to $\mathrm{NH}_{3}$.

\begin{tabular}{|c|c|c|c|c|c|c|c|}
\hline Catalytic materials & Catalysts & $T(\mathrm{~K})$ & Light source & Organic scavenger & $\begin{array}{c}\text { Average } \mathrm{NH}_{3} \\
\text { production rate }\end{array}$ & Year & Ref. \\
\hline \multirow{10}{*}{$\begin{array}{l}\text { Titanium oxide-based } \\
\text { materials }\end{array}$} & $\mathrm{TiO}_{2} @ \mathrm{C} / \mathrm{g}-\mathrm{C}_{3} \mathrm{~N}_{4}$ & ACs & Visible light & $\mathrm{CH}_{3} \mathrm{OH}$ & $250.6 \mu \mathrm{mol} \mathrm{g}^{-1} \mathrm{~h}^{-1}$ & 2018 & [20] \\
\hline & $\mathrm{Pb} / \mathrm{Fe}_{2} \mathrm{O}_{3}-\mathrm{TiO}_{2}$ & 298 & Xenon light & Distilled water & $1150 \mu \mathrm{M} \cdot \mathrm{h}^{-1}$ & 2017 & [21] \\
\hline & $\mathrm{Fe}$-doped $\mathrm{TiO}_{2}$ & - & UV & Ethanol & $400 \mu \mathrm{M} \cdot \mathrm{h}^{-1}$ & 2014 & [22] \\
\hline & $\mathrm{RuCl}_{3}-\mathrm{TiO}_{2}$ & RT & $\mathrm{UV}-\mathrm{V}$ is & Humic acid & $4 \mu \mathrm{M} \cdot \mathrm{h}^{-1} \cdot \mathrm{cm}^{-2}$ & 2008 & [23] \\
\hline & $\mathrm{P}_{3} \mathrm{MeT} / \mathrm{TiO}_{2}$ & 293 & UV & None & $8.3 \mu \mathrm{mol} \cdot \mathrm{h}^{-1} \cdot \mathrm{m}^{-2}$ & 2001 & [24] \\
\hline & Fe-doped $\mathrm{TiO}_{2}$ & 313 & $\mathrm{UV}-\mathrm{V}$ is & None & $10 \mu \mathrm{mol} \cdot \mathrm{g}^{-1} \cdot \mathrm{h}^{-1}$ & 1997 & [13] \\
\hline & Ru-doped $\mathrm{TiO}_{2}$ & - & $\mathrm{UV}-\mathrm{V}$ is & None & $22.7 \mu \mathrm{mol} \cdot \mathrm{g}^{-1} \cdot \mathrm{h}^{-1}$ & 1996 & [19] \\
\hline & $\mathrm{Fe}^{3+}$-doped $\mathrm{TiO}_{2}$ & 353 & UV & None & $6 \mu \mathrm{mol} \cdot \mathrm{g}^{-1} \cdot \mathrm{h}^{-1}$ & 1991 & [25] \\
\hline & $\mathrm{TiO}_{2}$ & RT & UV & Wet nitrogen flux & $0.83 \mu \mathrm{mol} \mathrm{g}^{-1} \mathrm{~h}^{-1}$ & 1988 & [26] \\
\hline & $\mathrm{BaTiO}_{3}$ & 313 & UV & None & $0.87 \mu \mathrm{mol} \cdot \mathrm{g}^{-1} \cdot \mathrm{h}^{-1}$ & 1983 & [27] \\
\hline \multirow{9}{*}{$\begin{array}{l}\text { Other metal oxide-based } \\
\text { materials }\end{array}$} & g- $\mathrm{C}_{3} \mathrm{~N}_{4} / \mathrm{Mg}_{1.1} \mathrm{Al}_{0.3} \mathrm{Fe}_{0.2} \mathrm{O}_{1.7}$ & 303 & Visible light & Ethanol & $166.8 \mu \mathrm{M} \cdot \mathrm{h}^{-1}$ & 2017 & [28] \\
\hline & $\mathrm{BiO}$ & ACs & Solar light & Deionized water & $50.5 \mu \mathrm{M} \cdot \mathrm{h}^{-1}$ & 2017 & [29] \\
\hline & $\mathrm{Fe}_{2} \mathrm{O}_{3}$ & 298 & $\mathrm{UV}-\mathrm{Vis}$ & Ethanol & $1362.5 \mu \mathrm{M} \cdot \mathrm{h}^{-1}$ & 2017 & [21] \\
\hline & $\mathrm{H}-\mathrm{Bi}_{2} \mathrm{MoO}_{6}$ & RT & Solar light & None & $1300 \mu \mathrm{mol} \mathrm{g}^{-1} \mathrm{~h}^{-1}$ & 2016 & [30] \\
\hline & $\mathrm{BiOBr}$ & RT & Visible light & None & $1042 \mu \mathrm{M} \cdot \mathrm{h}^{-1}$ & 2015 & [31] \\
\hline & $\beta-\mathrm{Ga}_{2} \mathrm{O}_{3}$ & 298 & UV & Tert-butanol & $36.1 \%$ & 2015 & [32] \\
\hline & Pt-loaded ZnO & - & UV & Na-EDTA & $860 \mu \mathrm{mol} \cdot \mathrm{g}^{-1} \cdot \mathrm{h}^{-1}$ & 2010 & [33] \\
\hline & $\mathrm{Cu}_{2} \mathrm{O} \cdot x \mathrm{H}_{2} \mathrm{O} \cdot \mathrm{CuCl}$ & ACs & UV & None & $70 \mu \mathrm{M} \cdot \mathrm{h}^{-1}$ & 1989 & [34] \\
\hline & $\mathrm{Fe}_{2} \mathrm{O}_{3}+\mathrm{Fe}_{3} \mathrm{O}_{4}$ & 303 & Xenon light & None & $10 \mu \mathrm{mol} \cdot \mathrm{g}^{-1} \cdot \mathrm{h}^{-1}$ & 1987 & [35] \\
\hline
\end{tabular}

$\mathrm{RT}$ denotes room temperature. ACs denote ambient conditions.

TABLE 3: Summary of metal sulfide-based materials for photocatalytic reduction of $\mathrm{N}_{2}$ to $\mathrm{NH}_{3}$.

\begin{tabular}{|c|c|c|c|c|c|c|c|}
\hline $\begin{array}{l}\text { Catalytic } \\
\text { materials }\end{array}$ & Catalysts & $T(\mathrm{~K})$ & Light source & Organic scavenger & $\begin{array}{l}\text { Average } \mathrm{NH}_{3} \\
\text { production rate }\end{array}$ & Year & Ref. \\
\hline \multirow{8}{*}{$\begin{array}{l}\text { Metals } \\
\text { sulfide-based } \\
\text { materials }\end{array}$} & $\mathrm{MoS}_{2}$ & 298 & Xenon light & None & $325 \mu \mathrm{mol} \cdot \mathrm{g}^{-1} \cdot \mathrm{h}^{-1}$ & 2017 & [12] \\
\hline & {$\left[\mathrm{Mo}_{2} \mathrm{Fe}_{6} \mathrm{~S}_{8}(\mathrm{SPh})_{3}\right]-\left[\mathrm{Fe}_{4} \mathrm{~S}_{4}\right]$} & ACs & Xenon light & None & $18.82 \mu \mathrm{M} \cdot \mathrm{h}^{-1}$ & 2016 & [36] \\
\hline & $\mathrm{Mo}_{0.1} \mathrm{Ni}_{0.1} \mathrm{Cd}_{0.8} \mathrm{~S}$ & 303 & Visible light & Ethanol & $71.2 \mu \mathrm{M} \cdot \mathrm{h}^{-1}$ & 2016 & [37] \\
\hline & $\mathrm{Zn}_{0.1} \mathrm{Sn}_{0.1} \mathrm{Cd}_{0.8} \mathrm{~S}$ & 303 & Visible light & Ethanol & $105.2 \mu \mathrm{M} \cdot \mathrm{h}^{-1}$ & 2016 & [38] \\
\hline & {$\left[\mathrm{Mo}_{2} \mathrm{Fe}_{6} \mathrm{~S}_{8}(\mathrm{SPh})_{3}\right]^{3+}$ and $\left[\mathrm{Sn}_{2} \mathrm{~S}_{6}\right]^{4-}$} & RT & Solar light & - & $18.82 \mu \mathrm{M} \cdot \mathrm{h}^{-1}$ & 2015 & [39] \\
\hline & $\mathrm{Pt} / \mathrm{CdS} \cdot \mathrm{Ag}_{2} \mathrm{~S} / \mathrm{RuO}_{2}$ & 303 & Visible light & $\mathrm{K}\left[\mathrm{Ru}(\right.$ EDTA-H $) \mathrm{Cl}_{2} \mathrm{H}_{2} \mathrm{O}$ & $1260 \mu \mathrm{M} \cdot \mathrm{h}^{-1}$ & 1991 & [40] \\
\hline & $\mathrm{CdS} / \mathrm{Pt} / \mathrm{RuO} 2$ & 303 & Visible light & None & $620 \mu \mathrm{M} \cdot \mathrm{h}^{-1}$ & 19 & [41] \\
\hline & $\mathrm{CdS} / \mathrm{Pt}$ & 311 & UV & None & $3.26 \mu \mathrm{mol} \cdot \mathrm{g}^{-1} \cdot \mathrm{h}^{-1}$ & 1980 & [42] \\
\hline
\end{tabular}

RT denotes room temperature. ACs denotes ambient conditions.

enhance the separation of charge carriers and also demonstrated this hypothesis. However, Soria et al. [25] suggested that excess $\mathrm{Fe}$ dopants might lead $\mathrm{TiO}_{2}$ materials to lose themselves all photocatalytic activities. Therefore, the low bulk $\mathrm{Fe}^{3+}$ concentrations significantly assist in charge separation. $\mathrm{TiO}_{2}$ nanoparticles codoped with $\mathrm{N}_{2}$ and $\mathrm{Fe}^{3+}$ were prepared using the homogeneous precipitation-hydrothermal method. The cooperation of $\mathrm{N}_{2}$ and $\mathrm{Fe}^{3+}$ leads to narrow the band gap, improve the photocatalytic activity in the visible light region, and promote the separation of the photogenerated electrons and holes to accelerate the transmission of the photocurrent carrier [49].

Generally, titanium oxide-based photocatalytic materials for the $\mathrm{N}_{2}$ reduction have made much progress in several aspects, such as the importance of iron dopants. However, some atomic-scale behaviours of $\mathrm{TiO}_{2}$ photocatalytic $\mathrm{N}_{2}$ reduction to $\mathrm{NH}_{3}$ are chaos, such as the $\mathrm{N} \equiv \mathrm{N}$ dissociation transition-states and active sites of $\mathrm{TiO}_{2}$ photocatalytic materials. Future research works should mainly discover the secrets on how to reduce $\mathrm{N}_{2}$ to $\mathrm{NH}_{3}$ in the presence of titanium-based materials from a molecular-level viewpoint.
3.1.2. Transition Metal-Doped Materials. Transition metals as dopants in photocatalytic materials have some advantages for the higher $\mathrm{NH}_{3}$ yields, such as less charge carrier recombination, stronger photocatalyst absorbance, and lower overpotential for the $\mathrm{N}_{2}$ reduction. In the process of preparing titanium-based photocatalytic materials for $\mathrm{NH}_{3}$ synthesis, preprocessing titanium-based materials with high temperatures $\left(\approx 1000^{\circ} \mathrm{C}\right)$ and adding transition metal impurities $(<1 \%)$ were necessary and benefit to obtain efficient titanium dioxide-based photocatalytic materials [46]. Since then, $\mathrm{CuCl}, \mathrm{WO}_{3}$, and $\mathrm{FeO} x$ as photocatalysts for $\mathrm{NH}_{3}$ synthesis from $\mathrm{N}_{2}$ have been investigated [34, 50]. Those surface oxygen defects of titanium metal could play an important role in the atmospheric $\mathrm{N}_{2}$ photoreduction.

Some transition metals taking place of iron as dopants in $\mathrm{TiO}_{2}$ materials were investigated [13], such as Co, Mo, $\mathrm{Ni}, \mathrm{Pd}, \mathrm{V}, \mathrm{Cr}, \mathrm{Cu}, \mathrm{Pt}, \mathrm{Ag}, \mathrm{Au}$, and $\mathrm{Pb}$. Only did $\mathrm{Co}, \mathrm{Mo}$, and Ni dopants among these metals enhance the $\mathrm{NH}_{3}$ yields, and the other metals not. Differently, Palmisano found that chromium-doped $\mathrm{TiO}_{2}$ material was effective in the photocatalytic $\mathrm{N}_{2}$ reduction to $\mathrm{NH}_{3}$ [51]. Besides their dopant 
role, transition metals on the surface of $\mathrm{TiO}_{2}$ materials could be effective in $\mathrm{NH}_{3}$ synthesis as cofactors of photocatalysts. For example, Ru-doped $\mathrm{TiO}_{2}$ could photocatalyze the reduction of $\mathrm{N}_{2}$ to $\mathrm{NH}_{3}$ [42]. As cocatalysts of $\mathrm{TiO}_{2}$ materials, the photocatalytic activities of transition metals are associated with the strength of the $\mathrm{M}-\mathrm{H}$ bonds ( $\mathrm{M}$ : transition metal), such as $\mathrm{Ru}>\mathrm{Rh}>\mathrm{Pd}>\mathrm{Pt}[19]$.

Due to lower Fermi level than the others, transitionmetal dopants as electron sinks in titanium photocatalysts could minimize the probability of carrier recombination to promote greater $\mathrm{NH}_{3}$ yields, which is a critical factor for designing photocatalytic systems. To increase $\mathrm{N}_{2}$ reduction driving force to $\mathrm{NH}_{3}$ synthesis, Co, Mo, Ni, Ru, and Pt dopants have been added into the titanium-based materials, respectively, which resulted in increasing the $\mathrm{NH}_{3}$ yields $[9,19]$. Anatase $\mathrm{TiO}_{2}$ was prepared by the sol-gel method through the hydrolysis of titanium tetrachloride and doped with transition metal ions like $\mathrm{V}^{5+}$ and $\mathrm{Zn}^{2+}$. Although both doped samples showed similar red shift in the band gap, $\mathrm{Zn}^{2+}$ (0.06 at.\%) doped $\mathrm{TiO}_{2}$ materials showed enhanced activity which was attributed to smaller crystallite size and larger surface area for accelerating the interfacial charge transfer [52]. Under ambient temperature and atmosphere, the photocatalytic activity of the $\mathrm{Ag}-\mathrm{TiO}_{2}$ multiphase nanocrystal composite thin films prepared by the liquid phase deposition method exceeded that of pure $\mathrm{TiO}_{2}$ thin films when the $\mathrm{AgNO}_{3}$ concentration was kept in the range of 0.03-0.05 [53]. The presence of dopants in the band gap could effectively improve photocatalytic performance through inducing defect states which assist in charge separation of photogenerated electrons and holes [26]. However, all transition metal dopants did not show more perfect photocatalytic activities than iron dopant in the $\mathrm{TiO}_{2}$ photocatalytic $\mathrm{NH}_{3}$ synthesis process [54]. Due to their lower Fermi level, transition metals act as electron sinks which creates a Schottky barrier, trapping photogenerated electrons and minimizing the probability for carrier recombination [20]. Therefore, reducing carrier recombination is a significant issue to design photocatalytic materials for the $\mathrm{NH}_{3}$ synthesis from $\mathrm{N}_{2}$.

3.1.3. Other Metal Oxide-Based Materials. In addition to titanium oxide-based materials, other metal oxide-based materials as photocatalyst have also obtained more and more attentions on their behaviours of reducing $\mathrm{N}_{2}$ to $\mathrm{NH}_{3}$ in the past several decades. All of these metal oxide-based materials reported have different degrees of photocatalytic activities for $\mathrm{NH}_{3}$ synthesis from $\mathrm{N}_{2}$ under ambient conditions.

Iron was early used as catalysts in the catalytic ammonia production processes by Dhar and Chowdhry [43]. As we know, iron plays an important role in the Haber-Bosch process, but it is ferric oxide $\left(\mathrm{Fe}_{2} \mathrm{O}_{3}\right)$ not iron as the alternative to titanium that could photocatalytic the reduction of $\mathrm{N}_{2}$ to $\mathrm{NH}_{3}$. However, pure $\mathrm{Fe}_{2} \mathrm{O}_{3}$ is not capable of photocatalytic $\mathrm{NH}_{3}$ synthesis from $\mathrm{N}_{2}$ unless partially reduced [20] and hydrous [23] $\mathrm{Fe}_{2} \mathrm{O}_{3}$. To solve the problem, Khader et al. [35] partially reduced a- $\mathrm{Fe}_{2} \mathrm{O}_{3}$ to $\mathrm{Fe}_{3} \mathrm{O}_{4}$ for photoactivating $\mathrm{N}_{2}$, which resulted in detecting $\mathrm{NH}_{3}$ in aqueous slurry of the catalyst. Furthermore, the photoactivity of mesoporous $\beta-\mathrm{Ga}_{2} \mathrm{O}_{3}$ nanorods in $\mathrm{N}_{2}$ photoreduction was ameliorated in the presence of different alcohols, such as ethanol and tert-butanol [32]. Besides $\mathrm{ZnO}$ prepared by means of wet etching or precipitation methods, it was reported that the $\mathrm{NH}_{3}$ yield of unmodified $\mathrm{ZnO}$ was higher than that of Pt-loaded $\mathrm{ZnO}$ materials [33].

As-synthesized bismuth monoxide $(\mathrm{BiO})$ materials were applied in the photocatalytic reduction of $\mathrm{N}_{2}$ to $\mathrm{NH}_{3}$ under solar light. Research results [28] showed that the $\mathrm{NH}_{3}$ synthesis rate is up to $1226 \mathrm{mmol} \cdot \mathrm{g}^{-1} \cdot \mathrm{h}^{-1}$ which is about 1000 times higher than that of the $\mathrm{Fe}-\mathrm{TiO}_{2}$ photocatalyst (Table 2). Obviously, deactivation of this photocatalyst did not occur even after being used more than 120 hours. Bismuth oxyhalides, $\mathrm{BiOX}(X=\mathrm{Cl}, \mathrm{Br}$, and $\mathrm{I})$, have recently become popular due to their excellent applications in photocatalytic $\mathrm{NH}_{3}$ synthesis from $\mathrm{N}_{2}$. BiOBr has also been focused on their material defects. Li et al. [29] employed $\mathrm{BiOBr}$ nanosheets with oxygen vacancies (OVs) to reduce $\mathrm{N}_{2}$ under visible light, and the $\mathrm{N}_{2}$ reduction rate was estimated to be $104.2 \mathrm{mmol} \cdot \mathrm{h}^{-1}$. The structure of $\mathrm{BiOBr}$ provides enough space to polarize atoms, and the efficient separation and transformation of charge carriers must depend on the as-formed internal electric field [30]. Moreover, the large number of OVs on the surface of $\mathrm{BiOBr}$ hampered the recombination of electron-hole pairs.

Interestingly, except the $\mathrm{N}$-type semiconductors above, there are some P-type semiconductors which should be also suitable for the photocatalytic $\mathrm{N}_{2}$ reductions, such as $\mathrm{CrO}$, $\mathrm{MnO}, \mathrm{FeO}, \mathrm{NiO}, \mathrm{Cu}_{2} \mathrm{O}, \mathrm{VO}_{2}, \mathrm{Cr}_{2} \mathrm{O}_{3}$, and $\mathrm{Ag}_{2} \mathrm{O}$. In addition, being added into some impurity atoms such as boron atoms, aluminum atoms, indium atoms, and gallium atoms, the others would turn into P-type semiconductors whose conductivity (i.e., charge carriers) mainly depends on positive vacant holes.

So far, hydrated P-type semiconductors as photocatalysts have been mainly used to reduce $\mathrm{N}_{2}$ to $\mathrm{NH}_{3}$. Early in 1987, hydrous $\mathrm{FeO}$ photocatalysts were discovered by Tennakone et al. [55] and were superior to $\mathrm{TiO}_{2}$ in the case of reducing $\mathrm{N}_{2}$ to $\mathrm{NH}_{3}$ under visible light [56]. Hydrous $\mathrm{Cu}_{2} \mathrm{O}$ after impregnation with $\mathrm{CuCl}$ was able to photoreduce $\mathrm{N}_{2}$ to $\mathrm{NH}_{3}$. Presumably, the high $\mathrm{NH}_{3}$ yield resulted from the reduction sites $\mathrm{Cu}_{2} \mathrm{O} \cdot x \mathrm{H}_{2} \mathrm{O}$ [34]. In 1992, vanadium-doped hydrous FeO could enhance reducing $\mathrm{N}_{2}$ to $\mathrm{NH}_{3}$ and the average $\mathrm{NH}_{3}$ production rate was $200 \mathrm{mM} \cdot \mathrm{h}^{-1}$ or so, which benefited from the $\mathrm{V}$ impurities increasing vacant holes [57] whose concentration is much larger than the free electrons concentration. Therefore, the more the impurity is added, the higher the concentration of multivacant holes, the stronger the conductivity of the semiconductor.

3.1.4. Metal Sulfide-Based Materials. Similar to the metal oxide-based photocatalysts, metal sulfides have recently become a hot research topic in the field of photocatalytic $\mathrm{NH}_{3}$ synthesis due to their strong absorption of visible light (Table 3). The $\mathrm{NH}_{3}$ synthesis rate is up to $325 \mu \mathrm{mol} \cdot \mathrm{g}^{-1} \cdot \mathrm{h}^{-1}$ in the presence of ultrathin $\mathrm{MoS}_{2}$ as photocatalysts, but without 
charged excitons, the bulk $\mathrm{MoS}_{2}$ did not have the ability of reduction of $\mathrm{N}_{2}$ under the same conditions [32]. Miyama et al. [42] suggested that $\mathrm{NH}_{3}$ yield of $\mathrm{CdS} / \mathrm{Pt}$ binary photocatalysts was drastically higher than that of pristine $\mathrm{CdS}$ under UV irradiation. $\mathrm{CdS} / \mathrm{Pt} / \mathrm{RuO}_{2}$ [33] and $\mathrm{Pt} / \mathrm{CdS}$ $\mathrm{Ag}_{2} \mathrm{~S} / \mathrm{RuO}_{2}$ [31] photocatalysts were successively applied to reduce $\mathrm{N}_{2}$ to $\mathrm{NH}_{3}$ under visible light. The holes in the valence band trapped the electrons that released from $\mathrm{RuO}_{2}$. To keep the high photocatalytic activity of $\mathrm{CdS}$ for a longer time, maybe some measures must be taken to stop the degradation of $\mathrm{CdS}$ to $\mathrm{S}$ and $\mathrm{Cd}^{2+}$.

Multicomponent metal sulfides with sulphur vacancies, such as $\mathrm{Zn}_{0.1} \mathrm{Sn}_{0.1} \mathrm{Cd}_{0.8} \mathrm{~S}$ [34] and $\mathrm{Mo}_{0.1} \mathrm{Ni}_{0.1} \mathrm{Cd}_{0.8} \mathrm{~S}$ [27], could reduce $\mathrm{N}_{2}$ as photocatalysts under visible light, and the concentration of sulphur vacancies trapping electrons were linear related to the $\mathrm{NH}_{3}$ yields. In addition, G-C $\mathrm{N}_{4}$ / $\mathrm{ZnSnCdS}$ [42] and $\mathrm{g}-\mathrm{C}_{3} \mathrm{~N}_{4} / \mathrm{ZnMoCdS}$ [35] were, respectively, employed for the fixation of $\mathrm{N}_{2}$. A tight junction coupling between $\mathrm{g}-\mathrm{C}_{3} \mathrm{~N}_{4}$ and $\mathrm{ZnMoCdS}$ was the key for efficient charge transfer.

Only nitrogenases can catalyze reduction of $\mathrm{N}_{2}$ to $\mathrm{NH}_{3}$ at room temperature and atmospheric pressure [55]. The nitrogenase complex consists of two proteins: Fe-protein which is responsible for the supply of electrons and MoFe-protein which uses the provided electrons to reduce $\mathrm{N}_{2}$ to $\mathrm{NH}_{3}$ [57]. Mimicking the catalytic activity sites FeMocofactor of MoFe-protein, a synthetic complex of Fe, Mo, and $S$ should be taken into account, and organic-sulfide catalysts have also been designed for enhanced $\mathrm{N}_{2}$ fixation activity. Banergee et al. [39] demonstrated that synthetic FeMoS inorganic clusters could reduce $\mathrm{N}_{2}$ to $\mathrm{NH}_{3}$ in aqueous media under light, which showed that structural analogues of nitrogenase can be functional to photocatalytic $\mathrm{N}_{2}$ fixation. Katherine et al. [31] reported that cadmium sulfide (CdS) nanocrystals can be used to drive the enzymatic reduction of $\mathrm{N}_{2}$ to $\mathrm{NH}_{3}$ by photosensitizing the MoFeprotein of nitrogenase not ATP hydrolysis. Under optimal conditions, the turnover rate was 75 per minute, $63 \%$ of the ATP-coupled reaction rate for the nitrogenase complex. Both $\left[\mathrm{Mo}_{2} \mathrm{Fe}_{6} \mathrm{~S}_{8}(\mathrm{SPh})_{3}\right]$ and $\left[\mathrm{Fe}_{4} \mathrm{~S}_{4}\right]$ clusters comprised in nitrogenase could do so at ambient temperature and pressure, and results suggest [58] that the nitrogenase could keep its photocatalytic activity when the $\left[\mathrm{Fe}_{4} \mathrm{~S}_{4}\right]$ clusters were replaced with other inert ions such as $\mathrm{Sb}^{3+}, \mathrm{Sn}^{4+}$, and $\mathrm{Zn}^{2+}$. In this process, $\mathrm{Fe}$ is necessary but Mo is not; however it does not mean that $\mathrm{Mo}$ is not playing a role in $\mathrm{N}_{2}$ binding. In addition, the biohybrids of CdS and MoFe-protein provide a photochemical model for achieving the photocatalytic $\mathrm{NH}_{3}$ production process. Therefore, redox-active iron sulfide containing clusters with high-energy photoexcited states could photocatalyze the reduction of $\mathrm{N}_{2}$ to $\mathrm{NH}_{3}$.

\section{Conclusions}

Although the Haber-Bosch process is an important chemical industrial approach to the worldwide population, this traditional $\mathrm{NH}_{3}$ production process is a high energyconsumption and environmental pollution process. Therefore, there have been more and more research interests in photocatalytic reduction of $\mathrm{N}_{2}$ to $\mathrm{NH}_{3}$ in the past decades. Difficultly, photocatalytic $\mathrm{NH}_{3}$ synthesis from $\mathrm{N}_{2}$ also needs to overcome the energy barrier of $\mathrm{N} \equiv \mathrm{N}$ triple band under the spin-polarized plane-wave pseudopotential method. The Density-functional theory has been used to calculate the electronic band structures and the optical absorption spectra of nitrogen-doped and oxygen-deficient anatase $\mathrm{TiO}_{2}$. The calculated results are in good agreement with our experimental measurements. These calculations reveal that the optical absorption of nitrogen-doped $\mathrm{TiO}_{2}$ in the visible light region is primarily located between 400 and $500 \mathrm{~nm}$, while that of oxygen-deficient $\mathrm{TiO}_{2}$ is mainly above $500 \mathrm{~nm}$. These results have important implications for the understanding and further development of photocatalytic materials that are active under visible light. However, synthesis of photocatalytic $\mathrm{NH}_{3}$ is still kept in a laboratory-scale level.

This work would like to assist in understanding state-ofthe-art in the photocatalytic $\mathrm{NH}_{3}$ synthesis field for promoting the research field of $\mathrm{N}_{2}$ fixation. Past reports on photocatalytic $\mathrm{NH}_{3}$ synthesis focused primarily on titanium oxide-based materials. However, recent studies demonstrated that the $\mathrm{N}_{2}$ reduction could occur in different photocatalytic reaction systems composed of transition metal-doped materials, metal sulfide-based materials, and other metal oxide-based materials (e.g., P-type semiconductors) as photocatalysts, respectively. Unfortunately, up to our knowledge, no viable and efficient photocatalysts for sustainable $\mathrm{NH}_{3}$ synthesis could meet all requirements of an active, selective, scalable, long-lived catalyst. With the application of modern computational and experimental techniques, developing efficient photocatalysts should be encouraged to discover the mechanism on how $\mathrm{N}_{2}$ reduction happens with the photocatalysts in the molecular level.

\section{Conflicts of Interest}

The author declares that there are no conflicts of interest regarding the publication of this manuscript.

\section{Acknowledgments}

This work was supported by the China Scholarship Council (No. 201706565033).

\section{References}

[1] T. Kandemir, M. E. Schuster, A. Senyshyn, M. Behrens, and R. Schlögl, "The haber-bosch process revisited: on the real structure and stability of "ammonia iron" under working conditions," Angewandte Chemie International Edition, vol. 52, no. 48, pp. 12723-12726, 2013.

[2] V. Smil, Enriching the Earth: Fritz Haber, Carl Bosch, and the Transformation of World Food Production, MIT Press, Cambridge, MA, USA, 2004.

[3] R. D. Hill, R. G. Rinker, and H. Dale Wilson, "Atmospheric nitrogen fixation by lightning," Journal of the Atmospheric Sciences, vol. 37, no. 1, pp. 179-192, 1980.

[4] K. Tamaru, Catalytic Ammonia Synthesis: Fundamentals and Practice, Plenum Press, New York, NY, USA, 1991. 
[5] J. W. Erisman, A. Bleeker, J. Galloway, and M. S. Sutton, "Reduced nitrogen in ecology and the environment," Environmental Pollution, vol. 150, no. 1, pp. 140-149, 2007.

[6] M. A. Shipman and M. D. Symes, "Recent progress towards the electro-synthesis of ammonia from sustainable resources," Catalysis Today, vol. 286, pp. 57-68, 2017.

[7] T. Spatzal, "Reactive nitrogen-containing species: generation, characterization and functionalization," Journal of Inorganic and General Chemistry, vol. 641, no. 1, pp. 1-135, 2015.

[8] S. Giddey, S. P. S. Badwal, and A. Kulkarni, "Review of electrochemical ammonia production technologies and materials," International Journal of Hydrogen Energy, vol. 38, no. 34, pp. 14576-14594, 2013.

[9] A. J. Medford and M. C. Hatzell, "Photon-driven nitrogen fixation: current progress, thermodynamic considerations, and future outlook," ACS Catalysis, vol. 7, no. 4, pp. 2624$2643,2017$.

[10] C. J. vander Ham, M. T. Koper, and D. G. Hetterscheid, "Challenges in reduction of dinitrogen by proton and electron transfer," Chemical Society Reviews, vol. 43, no. 15, pp. 5183-5191, 2014.

[11] H. D. Wilson and R. G. Rinker, "Concentration forcing in ammonia synthesis-I Controlled cyclic operation," Chemical Engineering Science, vol. 37, no. 3, pp. 343-355, 1982.

[12] S. M. Sun, X. M. Li, W. Z. Wang, L. Zhang, and X. Sun, "Photocatalytic robust solar energy reduction of dinitrogen toammonia on ultrathin $\mathrm{MoS}_{2}$," Applied Catalysis B: Environmental, vol. 200, pp. 323-329, 2017.

[13] G. N. Schrauzer and T. D. Guth, "Photolysis of water and photoreduction of nitrogen on titanium dioxide," Journal of American Chemical Society, vol. 99, no. 22, pp. 7189-7193, 1977.

[14] H. Hirakawa, M. Hashimoto, Y. Shiraishi, and T. Hirai, "Photocatalytic conversion of nitrogen to ammonia with water on surface oxygen vacancies of titanium dioxide," Journal of American Chemical Society, vol. 139, no. 31, pp. 10929-10936, 2017.

[15] I. Roger, M. A. Shipman, and M. D. Symes, "Earth-abundant catalysts for electrochemical and photoelectrochemical water splitting," Nature Reviews Chemistry, vol. 1, no. 1, pp. 1-10, 2017.

[16] C. M. Thacker, H. O. Folkins, and E. L. Miller, "Free energies of formation of gaseous hydrocarbons and related substances," Industrial and Engineering Chemistry, vol. 33, no. 5, pp. 584-590, 1941.

[17] H. Li, J. Li, Z. H. Ai, F. L. Jia, and L. Z. Zhang, "Oxygen vacancy-mediated photocatalysis of BiOCl: reactivity, selectivity, and perspectives," Angewandte Chemie International Edition, vol. 57, no. 1, pp. 122-138, 2018.

[18] N. R. Dhar, E. Seshacharyulu, and N. Biswas, "New aspects of nitrogen fixation and loss in soils," Proceedings of National Academy of Sciences, India, vol. 7, no. 2, pp. 115-131, 1941.

[19] K. T. Ranjit, T. Varadarajan, and B. Viswanathan, "Photocatalytic reduction of dinitrogen to ammonia over noblemetal-loaded $\mathrm{TiO}_{2}$," Journal of Photochemistry and Photobiology A: Chemistry, vol. 96, no. 1-3, pp. 181-185, 1996.

[20] Q. X. Liu, L. H. Ai, and J. Jiang, "MXene-derived $\mathrm{TiO}_{2} @ \mathrm{C} / \mathrm{g}-$ $\mathrm{C}_{3} \mathrm{~N}_{4}$ heterojunctions for highly efficient nitrogen photofixation," Journal of Materials Chemistry A, vol. 6, no. 9, pp. 4102-4110, 2018.

[21] M. Lashgari and P. Zeinalkhani, "Photocatalytic $\mathrm{N}_{2}$ conversion to ammonia using efficient nanostructured solar-energymaterials in aqueous media: a novel hydrogenation strategy and basic understanding of the phenomenon," Applied Catalysis A: General, vol. 529, pp. 91-97, 2017.

[22] W. R. Zhao, J. Zhang, X. Zhu et al., "Enhanced nitrogen photofixation on Fe-doped $\mathrm{TiO}_{2}$ with highly exposed (101) facets in the presence of ethanol as scavenger," Applied Catalysis B: Environmental, vol. 144, pp. 468-477, 2014.

[23] O. P. Linnik and H. Kisch, "Dinitrogen photofixation at ruthenium-modified titania films," Mendeleev Communications, vol. 18, no. 1, pp. 10-11, 2008.

[24] K. Hoshino, "New avenues in dinitrogen fixation research," Chemistry-A European Journal, vol. 7, no. 13, pp. 2727-2731, 2001.

[25] J. Soria, J. C. Conesa, V. Augugliaro, L. Palmisano, M. Schiavello, and A. Sclafani, "Dinitrogen photoreduction to ammonia over titanium dioxide powders doped with ferric ions," Journal of Physical Chemistry, vol. 95, no. 1, pp. 274282, 1991.

[26] S. Bourgeois, D. Diakite, and M. Perdereau, "A study of $\mathrm{TiO}_{2}$ powders as a support for the photochemical synthesis of ammonia," Reactivity of Solids, vol. 6, no. 1, pp. 95-104, 1988.

[27] Q. S. Li, K. Domen, S. Naito, T. Onishi, and K. Tamaru, "Photocatalytic synthesis and photodecomposition of ammonia over $\mathrm{SrTiO}_{3}$ and $\mathrm{BaTiO}_{3}$ based catalysts," Chemistry Letters, vol. 12, no. 3, pp. 321-324, 1983.

[28] Y. J. Wang, W. S. Wei, M. Y. Li, S. Z. Hu, J. Zhang, and R. J. Feng, "In situ construction of Z-scheme g- $\mathrm{C}_{3} \mathrm{~N}_{4} /$ $\mathrm{Mg}_{1.1} \mathrm{Al}_{0.3} \mathrm{Fe}_{0.2} \mathrm{O}_{1.7}$ nanorod heterostructures with high $\mathrm{N}_{2}$ photofixation ability under visible light," RSC Advances, vol. 7, no. 29, pp. 18099-18107, 2017.

[29] H. Li, J. Shang, Z. Ai, and L. Zhang, "Efficient visible light nitrogen fixation with $\mathrm{BiOBr}$ nanosheets of oxygen vacancies on the exposed $\{001\}$ facets," Journal of the American Chemical Society, vol. 137, no. 19, pp. 6393-6399, 2015.

[30] Y. Hao, X. Dong, S. Zhai, H. Ma, X. Wang, and X. Zhang, "Hydrogenated bismuth molybdate nanoframe for efficient sunlight-driven nitrogen fixation from air," Chemistry-A European Journal, vol. 22, no. 52, pp. 18722-18728, 2016.

[31] K. Tennakone, O. A Ileperuma, C. T. K. Thaminimulla, and J. M. S. Bandara, "Photo-oxidation of nitrogen to nitrite using a composite $\mathrm{ZnO}-\mathrm{Fe}_{2} \mathrm{O}_{3}$ catalyst," Journal of Photochemistry and Photobiology A: Chemistry, vol. 66, no. 3, pp. 375-378, 1992.

[32] W. Zhao, H. Xi, M. Zhang et al., "Enhanced quantum yield of nitrogen fixation for hydrogen storage with in situ-formed carbonaceous radicals," Chemical Communications, vol. 51, no. 23, pp. 4785-4788, 2015.

[33] C. M. Janet, S. Navaladian, B. Viswanathan, T. K. Varadarajan, and R. P. Viswanath, "Heterogeneous wet chemical synthesis of superlattice-type hierarchical $\mathrm{ZnO}$ architectures for concurrent $\mathrm{H} 2$ production and N2 reduction," Journal of Physical Chemistry C, vol. 114, no. 6, pp. 2622-2632, 2010.

[34] K. Tennakone, S. Punchihewa, and R. Tantrigoda, "Nitrogen photoreduction with cuprous chloride coated hydrous cuprous oxide," Solar Energy Materials, vol. 18, no. 3-4, pp. 217-221, 1989.

[35] M. M. Khader, N. N. Lichtin, G. H. Vurens, M. Salmeron, and G. A. Somorjai, "Photoassisted catalytic dissociation of $\mathrm{H}_{2} \mathrm{O}$ and reduction of $\mathrm{N}_{2}$ to $\mathrm{NH}_{3}$ on partially reduced $\mathrm{Fe}_{2} \mathrm{O}_{3}$," Langmuir, vol. 3, no. 2, pp. 303-304, 1987.

[36] J. Liu, M. S. Kelley, W. Q. Wu et al., "Nitrogenase-mimic ironcontaining chalcogels for photochemical reduction of dinitrogen to ammonia," Proceedings of the National Academy of Sciences, vol. 113, no. 20, pp. 5530-5535, 2016. 
[37] Y. Cao, S. Hu, F. Li et al., "Photofixation of atmospheric nitrogen to ammonia with a novel ternary metal sulfide catalyst under visible light," RSC Advances, vol. 6, no. 55, pp. 49862-49867, 2016.

[38] S. Z. Hu, X. Chen, Q. Li, Y. F. Zhao, and W. Mao, "Effect of sulfur vacancies on the nitrogen photofixation performance of ternary metal sulfide photocatalysts," Catalysis Science \& Technology, vol. 6, no. 15, pp. 5884-5890, 2016.

[39] A. Banerjee, B. D. Yuhas, E. A. Margulies et al., "Photochemical nitrogen conversion to ammonia in ambient conditions with FeMoS-chalcogels," Journal of the American Chemical Society, vol. 137, no. 5, pp. 2030-2034, 2015.

[40] M. M. T. Khan and N. N. Rao, "Stepwise reduction of coordinated dinitrogen to ammonia via diazinido and hydrazido intermediates on a visible light irradiated Pt/CdS $\cdot \mathrm{Ag}_{2} \mathrm{~S} / \mathrm{RuO}_{2}$ particulate system suspended in an aqueous solution of $\mathrm{K}[\mathrm{Ru}$ (EDTA-H) $\mathrm{Cl}_{2} \mathrm{H}_{2} \mathrm{O}$," Journal of Photochemistry and Photobiology A: Chemistry, vol. 56, no. 1, pp. 101-111, 1991.

[41] M. M. T. Khan, R. C. Bhardwaj, and C. Bhardwaj, "Catalytic fixation of nitrogen by the photocatalytic $\mathrm{CdS} / \mathrm{Pt} / \mathrm{RuO}_{2}$ particulate system in the presence of aqueous [Ru(hedta) $\mathrm{N}_{2}$ ] complex," Angewandte Chemie International Edition in English, vol. 27, no. 7, pp. 923-925, 1988.

[42] H. Miyama, N. Fujii, and Y. Nagae, "Heterogeneous photocatalytic synthesis of ammonia from water and nitrogen," Chemical Physics Letters, vol. 74, no. 3, pp. 523-524, 1980.

[43] N. R. Dhar and S. Chowdhry, "Fixation of nitrogen in presence of pure oxide surfaces by the slow oxidation of energy materials," Proceedings of National Academy of Sciences, India, vol. 38, no. 3-4, pp. 485-490, 1968.

[44] V. Augugliaro, A. Lauricella, L. Rizzuti, M. Schiavello, and A. Sclafani, "Conversion of solar energy to chemical energy by photoassisted processes-I. Preliminary results on ammonia production over doped titanium dioxide catalysts in a fluidized bed reactor," International Journal of Hydrogen Energy, vol. 7, no. 11, pp. 845-849, 1982.

[45] G. N. Schrauzer, Photoreduction of Nitrogen on $\mathrm{TiO}_{2}$ and $\mathrm{TiO}_{2}$-Containing Minerals, Energy Efficiency and Renewable Energy Through Nanotechnology, Springer, Berlin, Germany, 2011.

[46] U. Diebold, "The surface science of titanium dioxide," Surface Science Reports, vol. 48, no. 5-8, pp. 53-229, 2003.

[47] V. Augugliaro, F. Dalba, L. Rizzuti, M. Schiavello, and A. Sclafani, "Conversion of solar energy to chemical energy by photoassisted processes-II. Influence of the iron content on the activity of doped titanium dioxide catalysts for ammonia photoproduction," International Journal of Hydrogen Energy, vol. 7, no. 11, pp. 851-855, 1982.

[48] K. T. Ranjit and B. Viswanathan, "Synthesis, characterization and photocatalytic properties of iron-doped TiO catalysts," Journal of Photochemistry and Photobiology A: Chemistry, vol. 108, no. 1, pp. 79-84, 1997.

[49] Y. Cong, J. L. Zhang, F. Chen, M. Anpo, and D. N. He, "Preparation, photocatalytic activity, and mechanism of nano-tio ${ }_{2}$ Co-doped with nitrogen and iron (III)," Journal of Physical Chemistry C, vol. 111, no. 28, pp. 10618-10623, 2007.

[50] S. Yamazoe, Y. Masutani, K. Teramura, Y. Hitomi, T. Shishido, and T. Tanaka, "Promotion effect of tungsten oxide on photo-assisted selective catalytic reduction of $\mathrm{NO}$ with $\mathrm{NH}_{3}$ over $\mathrm{TiO}_{2}$," Applied Catalysis B: Environmental, vol. 83, no. 1-2, pp. 123-130, 2008.

[51] L. Palmisano, V. Augugliaro, A. Sclafani, and M. Schiavello, "Activity of chromium-ion-doped titania for the dinitrogen photoreduction to ammonia and for the phenol photodegradation," Journal of Physical Chemistry, vol. 92, no. 23, pp. 6710-6713, 1988.

[52] L. G. Devi, B. N. Murthy, and S. G. kumar, "Photocatalytic activity of $\mathrm{TiO}_{2}$ doped with $\mathrm{Zn}^{2+}$ and $\mathrm{V}^{5+}$ transition metal ions: influence of crystallite size and dopant electronic configuration on photocatalytic activity," Materials Science and Engineering: B, vol. 166, no. 1, pp. 1-6, 2010.

[53] J. G. Yu, J. F. Xiong, B. Cheng, and S. W. Liu, "Fabrication and characterization of $\mathrm{Ag}-\mathrm{TiO}_{2}$ multiphase nanocomposite thin films with enhanced photocatalytic activity," Applied Catalysis B: Environmental, vol. 60, no. 3-4, pp. 211-221, 2005.

[54] M. R. Hoffmann, S. T. Martin, W. Choi, and D. W. Bahnemann, "Environmental applications of semiconductor photocatalysis," Chemicals Reviews, vol. 95, no. 1, pp. 69-96, 1995.

[55] K. Tennakone, S. Wickramanayake, C. A. N. Fernando, O. A. Ileperuma, and S. J. Punchihewa, "Photocatalytic nitrogen reduction using visible light," Journal of the Chemical Society, Chemical Communications, no. 14, pp. 1078-1080, 1987.

[56] K. Tennakone, J. M. S. Bandara, C. T. K. Thaminimulla et al., "Photoreduction of dinitrogen to ammonia by ultrafine particles of iron hydroxide oxide $(\mathrm{Fe}(\mathrm{O}) \mathrm{OH})$ formed by photohydrolysis of iron(II) bicarbonate," Langmuir, vol. 7, no. 10, pp. 2166-2168, 1991.

[57] K. Tennakone, C. T. K. Thaminimulla, and J. M. S. Bandara, "Nitrogen photoreduction by vanadium(III)-substituted hydrous ferric oxide," Journal of Photochemistry and Photobiology A: Chemistry, vol. 68, no. 2, pp. 131-135, 1992.

[58] S. M. Sun, Q. An, W. Z. Wang, L. Zhang, J. J. Liu, and W. A. Goddard III, "Efficient photocatalytic reduction of dinitrogen to ammonia on bismuth monoxide quantum dots," Journal of Materials Chemistry A, vol. 5, no. 1, pp. 201-209, 2017. 

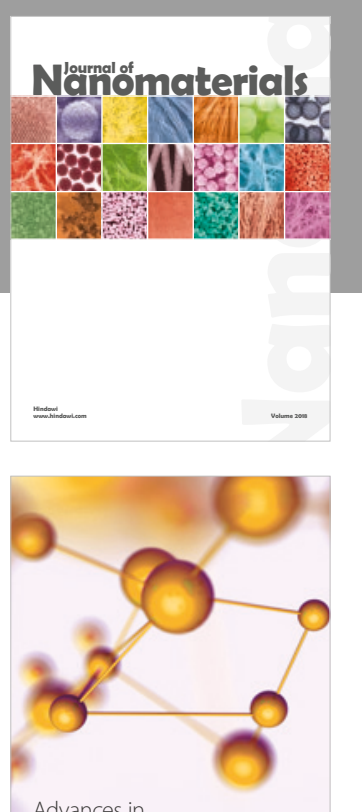

Physical Chemistry
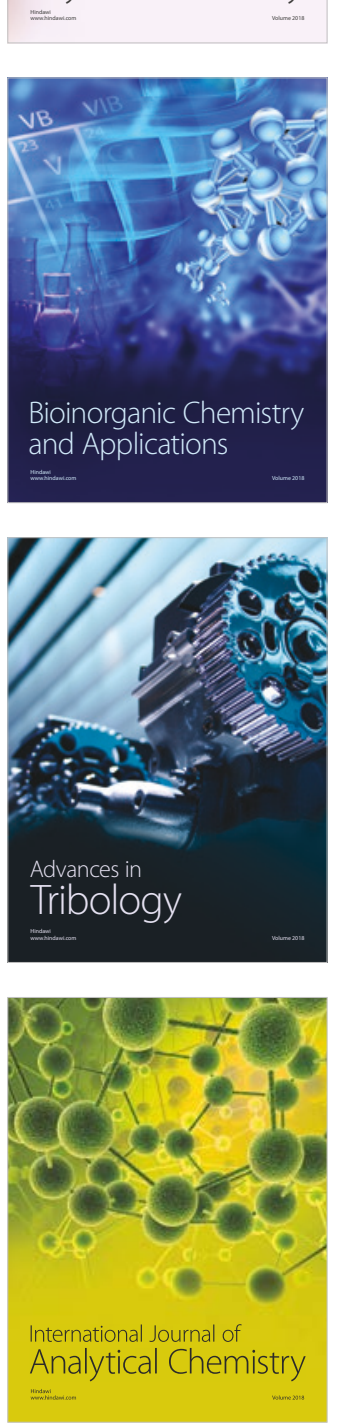

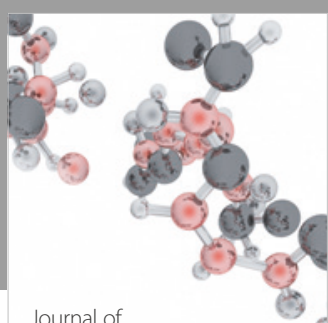

Analytical Methods

in Chemistry

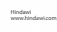

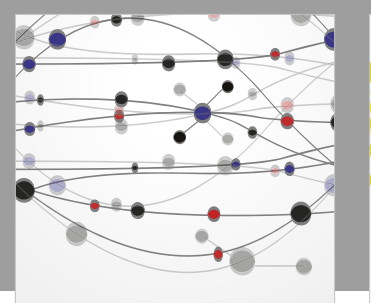

The Scientific World Journal

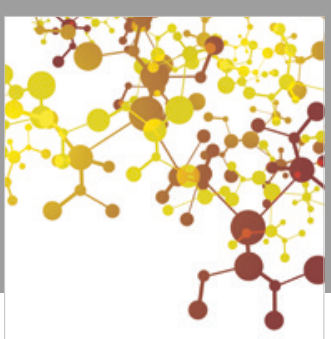

Journal of

Applied Chemistry
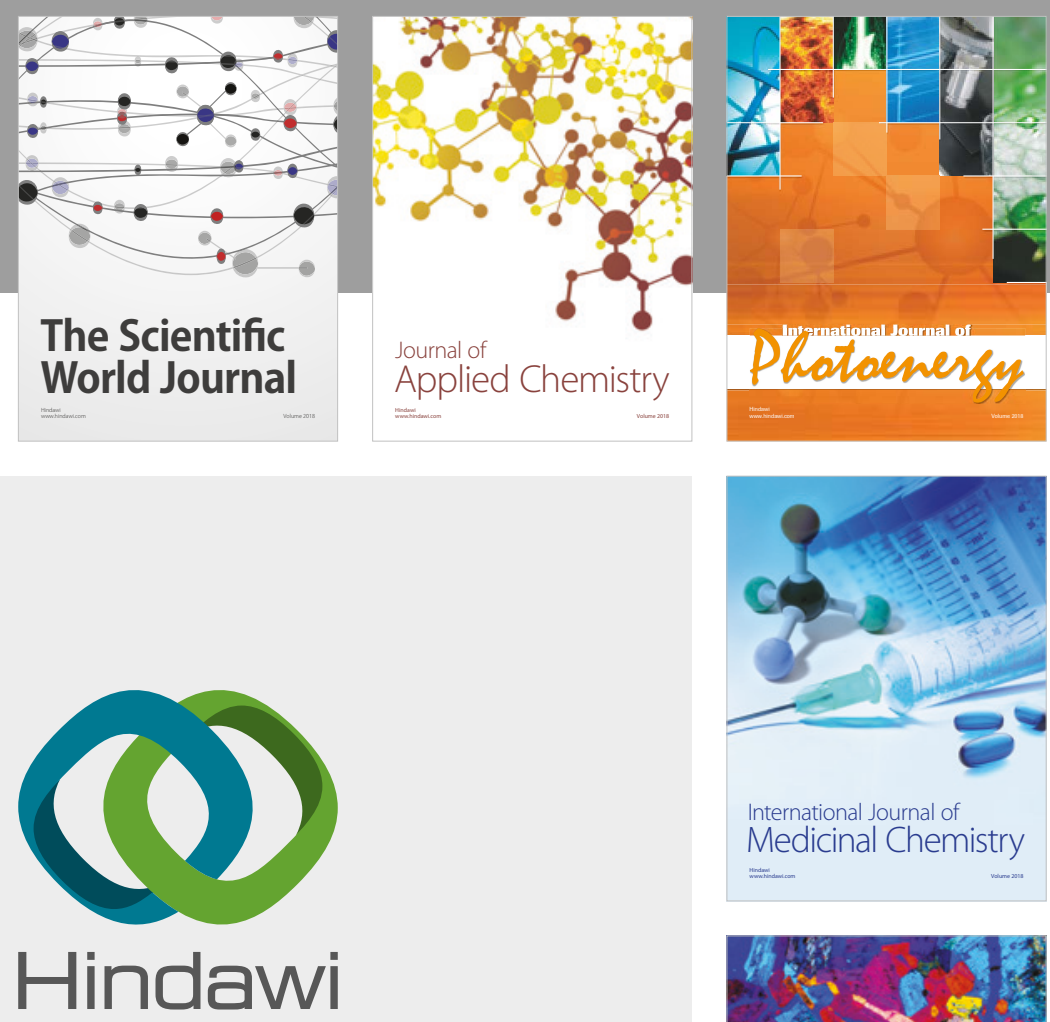

Submit your manuscripts at

www.hindawi.com
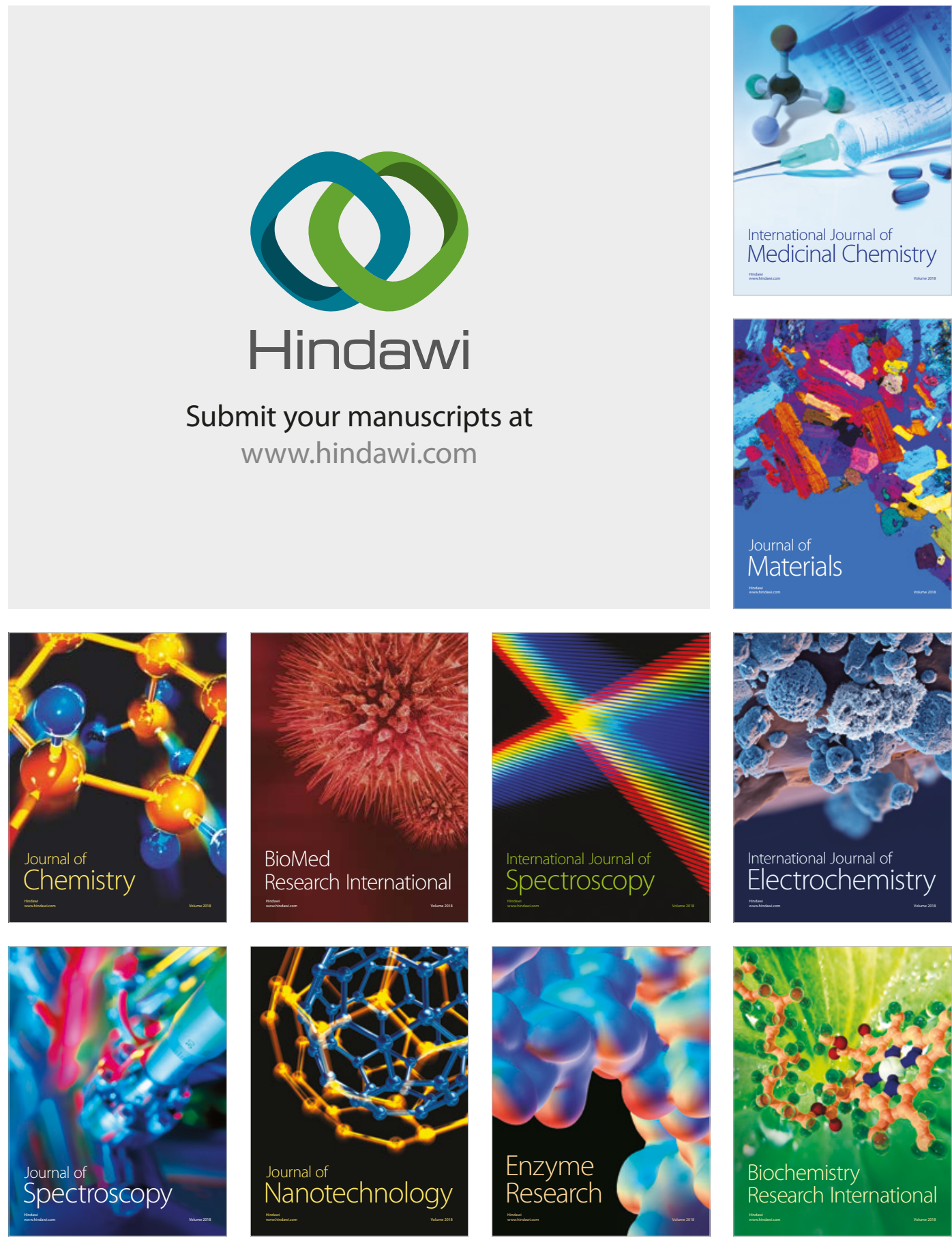
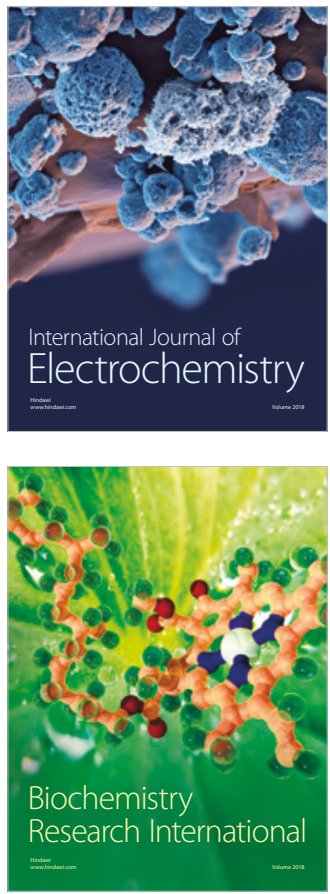